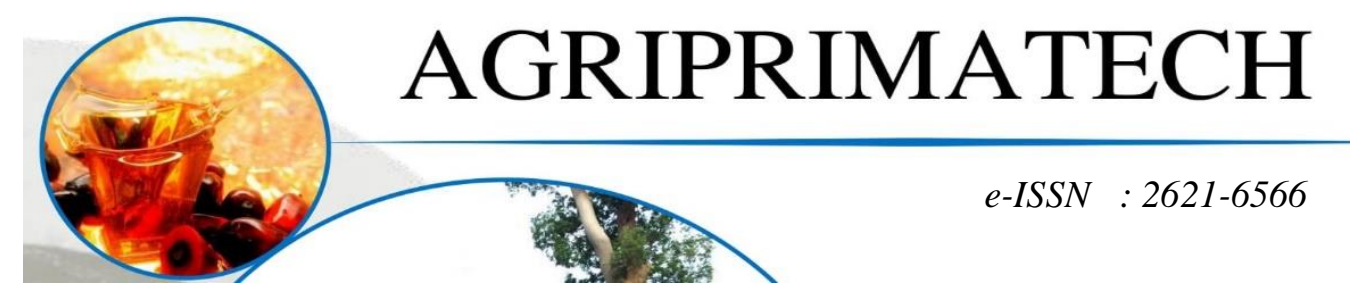

\title{
FAKTOR-FAKTOR YANG MEMPENGARUHI ADOPSI BIBIT BERSERTIFIKAT PADA PERKEBUNAN RAKYAT(Studi pada Petani Kelapa Sawit di Kecamatan Bilah Hulu Kabupaten Labuhan Batu)
}

\author{
ABEDNEGO SURANTA KARO SEKALI ${ }^{1}$, SURATNI AFRIANTI' ${ }^{2}$ NURSYANI \\ TRISNANDA ${ }^{2}$ \\ 1,2 Fakultas Agroteknologi, Universitas Prima Indonesia, Sumatera Utara \\ Email: abednegoks@unprimdn.ac.id
}

\begin{abstract}
ABSTRAK
Penelitian ini bertujuan untuk menganalisis penggunaan bibit kelapa sawit bersertifikat pada perkebunan rakyat di Kecamatan Bilah Hulu, Kabupaten Labuhan Batu, Sumatera Utara. Model yang digunakan untuk menjelaskan penggunaan bibit kelapa sawit bersertifikat adalah DOI (Diffusion Of Innovation) dengan variabel Relative Advantage, Compatibility, Complexity, Triability, dan Observability. Metode yang digunakan untuk menguji pola hubungan korelasi variabel yaitu Analisis Linear Berganda dengan menggunakan program SPSS 24. Data penelitian ini adalah data primer diperoleh dengan menggunakan kuisioner yang dibagikan kepada petani kelapa sawit. Berdasarkan hasil regresi dan analisis data menggunakan uji t, nilai thitung pada variabel Relative Advantage sebesar 2.747, Complexity sebesar 2.762, dan Triability sebesar 4,922 lebih besar dari nilai $t_{\text {tabel }} 1,660$ yang artinya memiliki pengaruh positif dan signifikan terhadap adopsi bibit kelapa sawit bersertifikat, sedangkan nilai thitung variabel Compatibility sebesar 1,351, dan Observability sebesar 1.543 lebih kecil dari nilai $t_{\text {tabel }} 1,660$ yang artinya tidak memiliki pengaruh signifikan terhadap niat petani mengadopsi bibit kelapa sawit bersertifikat. Hasil uji koefisien determinasi $\left(\mathrm{R}^{2}\right)$ menunjukkan bahwa variabel Relative Advantage, Compatibility, Complexity, Triability, dan Observability mampu menjelaskan variabel dependent yaitu Adoption sebesar 42,4\% dan sisanya 57,6 \% dijelaskan oleh variabelvariabel lain di luar model. Pengujian secara simultan menggunakan uji f dimana nilai $\mathrm{f}_{\text {hitung }}$ sebesar 13.859 lebih besar dari nilai $f_{\text {tabel }}$ 2,31. Artinya secara simultan variabel Relative Advantage, Compatibility, Complexity, Triability, dan Observability berpengaruh signifikan terhadap niat petani mengadopsi bibit kelapa sawit bersertifikat di Kecamatan Bilah Hulu Kabupaten Labuhan Batu Sumatera Utara.
\end{abstract}

Kata Kunci : Adoption, Analisis, Regresi, Bibit, Bersertifikat.

\section{PENDAHULUAN}

Kelapa sawit adalah tumbuhan industri / perkebunan yang berguna sebagai penghasil minyak makan, minyak industri, maupun bahan bakar (Lina Arliana Nur Kadim, 2014). 
Agriprimatech

Vol. 3 No. 2, April 2020

Perkebunan kelapa sawit dapat menghasilkan keuntungan besar sehingga banyak hutan dan perkebunan lama dikonveksikan menjadi perkebunan kelapa sawit. Berdasarkan data dari Ditjen Perkebunan, produksi kelapa sawit Indonesia ditahun 2015 tercatat mencapai 31,28 juta ton. Luas areal perkebunan kelapa sawit terdiri dari 50,77\% diusahakan oleh Perkebunan Besar Swasta (PBS), 37,45\% diusahakan oleh Perkebunan Rakyat (PR) dan sisanya diusahakan oleh Perkebunan Besar Negara (PBN). Berdasarkan data Food and Agriculture Organization (FAO), Indonesia merupakan negara produsen kelapa sawit terbesar didunia, sekaligus menjadi negara eksportir terbesar.

Menurut Abdurachman diacu dalam Outlook Komoditas Pertanian Perkebunan (2010), perkebunan kelapa sawit di Indonesia menjadi sangat berkembang pesat dikarenakan : 1) kebutuhan minyak nabati dunia cukup besar dan akan terus meningkat, sebagai akibat jumlah penduduk maupun tingkat konsumsi per kapita yang masih rendah, 2) diantara berbagai jenis tanaman penghasil minyak nabati, kelapa sawit tanaman dengan potensi produksi minyak tertinggi, dan 3) semakin berkembangnya jenis-jenis industri hulu pabrik kelapa sawit maupun industri hilir oleokimia dan oleomakanan (oleochemical dan oleofoods), hingga industri konversi minyak sawit sebagai bahan bakar biodiesel. Faktor tersebut memicu nilai kelapa sawit menjadi semakin tinggi sehingga pemerintah, swasta, dan masyarakat tertarik untuk mengembangkan komoditi kelapa sawit. Pengembangan perkebunan kelapa sawit, selain secara ekonomi menunjukkan peran yang tinggi sebagai penyumbang devisa, sekaligus dapat mencapai berbagai manfaat yang terkait langsung dengan pembangunan ekonomi nasional seperti pembangunan wilayah
e-ISSN : 2621-6566

bukaan baru, penyerapan tenaga kerja, dan peningkatan pendapatan petani.

Produktivitas kelapa sawit Indonesia relatif masih rendah. Rata-rata produktivitas kelapa sawit 3 - 4 ton per hektar. Jauh lebih rendah dari potensi produksinya yang bisa mencapai 8,6 ton/ha (Henson, 1990). Potensi peningkatan produksi didukung oleh sinar matahari yang hampir selalu ada sepanjang tahun, curah hujan yang tinggi, lahan yang kaya zat vulkanik, serta pemahaman yang baik tentang pengelolaan kelapa sawit. Senada dengan Henson 1990, Goenadi (2008) mengatakan bahwa melalui pemanfaatan sumber daya secara optimal disertai dengan penggunaan bibit kelapa sawit bersertifikat, potensi produksi tahunan dari segi genetik bisa mencapai $6-7$ ton per hektar. Salah satu penyebab rendahnya produktivitas sawit di Indonesia karena masih banyak petani yang menggunakan bibit tidak bersertifikat/palsu/asalan (Silala, 2003)

Mengingat pentingnya bibit bersertifikat bagi petani khususnya penggunaan bibit bersertifikat. Saat ini edukasi dibidang perkebunan terus digalakkan. Berbagai upaya dan usaha terus pula dikembangkan, baik yang dilakukan oleh pemerintah maupun bersama-sama antara pemerintah dan masyarakat. Salah satu upaya yang dilakukan dalam edukasi dibidang perkebunan kelapa sawit tersebut adalah dengan dilakukannya suatu pendekatan yaitu berupa pengenalan bibit bersertifikat. Penggunaan bibit bersertifikat adalah suatu usaha atau upaya untuk mengubah perilaku petani dan keluarganya, agar mengetahui dan mempunyai kemauan serta mampu memecahkan masalah dalam usaha ataukegiatan-kegiatanmeningkatkan

produktivitas usaha yang akandikembangkannya (Ume Humaedah, 2007). 
Agriprimatech

Vol. 3 No. 2, April 2020

Kegiatan pengenalan lebih diutamakan sebagai proses pendidikan dalam mengubah perilaku petani agar menjadi lebih berkualitas melalui proses komunikasi. Petani sering dihadapkan pada berbagai kendala dalam proses pengambilan keputusan penerapan suatu perubahan, karena banyaknya pertimbangan yang harus dilakukan petani sebelum memutuskan untuk mengadopsi suatu perubahan. Proses pengadopsian pada bibit kelapa sawit bersertifikat memerlukan komunikasi yang efektif. Sebelum proses adopsi terjadi, secara psikologis petani akan berusaha memahami, berdasarkan keinginan dan kebutuhan untuk mengetahui makna dari penerapan bibit bersertifikat yang diterimanya. Pemahaman (persepsi) petani tentang inovasi terbentuk melalui proses memilih atau menyaring berbagai informasi yang diterima petani. Persepsi petani akan mempengaruhi pengambilan keputusan dan tahapan penerapan inovasi berikutnya. Komunikasi yang efektif terjadi jika terdapat persamaan persepsi antara sumber pesan dengan petani sebagai penerima pesan menyangkut informasi yang disampaikan. Persepsi ini merupakan bagian dari keseluruhan proses yang menghasilkan tanggapan setelah sasaran mendapatkan stimulus dari lingkungan (Sobur, 2003).

\section{METODE PENELITIAN}

Tempat penelitian ini dilakukan di Aek Nabara Kecamatan Bilah Hulu Kabupaten Labuhan Batu dan waktu penelitian selama 1 bulan dimulai dari tanggal 25 Maret sampai 23 April 2019. Data yang dikumpulkan dalam penelitian ini menggunakan data primer yang diperoleh melalui wawancara langsung kepada petani kelapa sawit, dimana responden
e-ISSN :2621-6566

akan memberikan respon verbal atau respon tertulis sebagai tanggapan atas pernyataan yang diberikan. Sampel adalah sebagian dari populasi yang diteliti. Menurut Ferdinand (2006)jika penelitian bersifat deskriptif, maka umumnya membutuhkan sampel yang besar. Dalam penentuan jumlah sampel yang dibutuhkan dalam penelitian ini ditentukan dengan rumus Rao Purba (1996) yaitu :

Dimana :

$$
n=\frac{Z^{2}}{4(M o e)^{2}}
$$

$$
\begin{aligned}
\mathrm{n} \quad & \text { Besar sampel } \\
\mathrm{Z}= & \text { Tingkat distribusi normal pada } \\
& \text { taraf signifikan 10\% dengan } \\
& \text { menggunakan } \mathrm{t}_{\text {tabel }} \\
4 \quad & \text { Nilai konstanta } \\
\text { Moe = } & \text { Margin of error (error) atau } \\
& \text { kesalahan maksimal yang bisa } \\
& \text { dikolerasi, disini ditetapkan } \\
& 10 \% \text { atau 0,1. }
\end{aligned}
$$

$$
\begin{aligned}
& n=\frac{(1,66)^{2}}{4(0,1)^{2}} \\
& n=\frac{2,75}{0,04}
\end{aligned}
$$$$
n=68,75
$$

Dengan menggunakan margin of error sebesar $10 \%$, maka jumlah sampel minimal yang dapat diambil sebesar $n=$ 68,75atau 69 sampel minimum.

\section{Karakteristik Responden}

Karakteristik responden digunakan untuk mengetahui keragaman dari responden berdasarkan jenis kelamin, usia, dan hasil produksi perbulan. Hal tersebut diharapkan dapat memberikan gambaran yang cukup jelas mengenai kondisi dari responden dan kaitannya dengan masalah dan tujuan penelitian tersebut. Keragaman responden dapat ditunjukkan pada Tabel 1 berikut ini : 
Agriprimatech

Vol. 3 No. 2, April 2020

e-ISSN : 2621-6566

Tabel 1. Karakteristik Responden

\begin{tabular}{l|l|l}
\hline Berdasarkan & Kategori & Jumlah \\
\hline Jenis Kelamin & Pria & 73 \\
& Wanita & 27 \\
\hline \multirow{4}{*}{ Usia } & $31-40$ & 20 \\
& $41-50$ & 30 \\
& $51-60$ & 33 \\
& $>61$ & 17 \\
\hline \multirow{4}{*}{ Hasil Produksi } & $500-1000 \mathrm{~kg} / \mathrm{bln}$ & 5 \\
& $1100-2000 \mathrm{~kg} / \mathrm{bln}$ & 47 \\
& $2100-3000 \mathrm{~kg} / \mathrm{bln}$ & 38 \\
& $>3100 \mathrm{~kg} / \mathrm{bln}$ & 10 \\
\hline
\end{tabular}

Sumber : Hasil Penelitian, 2019 (Data Diolah)

Berdasarkan Tabel 1, dapat diketahui bahwa responden berdasarkan jenis kelamin diantaranya Pria sebanyak 73 orang atau $73 \%$ dan wanita sebanyak 27 orang atau $27 \%$. Responden berdasarkan usia dari umur 31-40 tahun berjumlah 20 orang atau sebanyak $20 \%$, umur $41-50$ tahun berjumlah 30 orang atau sebanyak $30 \%$, umur 51-60 tahun berjumlah 33 orang atau sebanyak $33 \%$, dan umur $>61$ tahun berjumlah 17 orang atau sebanyak 17\%. Responden berdasarkan hasil produksi $500-1000 \mathrm{~kg} / \mathrm{bln}$ berjumlah 5 orang atau sebanyak $5 \%$, hasil produksi 1100-2000 kg/bln berjumlah 47 orang atau sebanyak $47 \%$, hasil produksi 2100 -

$3000 \mathrm{~kg} / \mathrm{bln}$ berjumlah 38 orang atau sebanyak $38 \%$, dan hasil produksi $>3100$ $\mathrm{kg} / \mathrm{bln}$ berjumlah 10 orang atau sebanyak $10 \%$.

\section{Deskripsi Variabel}

1. Relative Advantage (Keuntungan Relatif)

Dalam hal ini dikemukakan angket mengenai Relative Advantage (Keuntungan Relatif) yang merupakan variabel bebas dari penelitian, sebagaimana terlihat pada Tabel berikut, hasil persentase jawaban responden berdasarkan Relative Advantage.

Tabel 2 : Responden terhadap Relative Advantage

\begin{tabular}{|c|c|c|c|c|c|c|c|c|c|c|c|c|}
\hline \multirow{2}{*}{ Butir } & \multicolumn{2}{|c|}{ STS } & \multicolumn{2}{|l|}{ TS } & \multicolumn{2}{|l|}{$\mathrm{N}$} & \multicolumn{2}{|l|}{5} & \multicolumn{2}{|c|}{ SS } & \multirow{2}{*}{$\begin{array}{l}\text { Total } \\
\text { F }\end{array}$} & \multirow{2}{*}{$\begin{array}{l}\text { Total } \\
\%\end{array}$} \\
\hline & $F$ & $\%$ & E & $\%$ & $F$ & $\%$ & $F$ & $\%$ & $F$ & $\%$ & & \\
\hline & 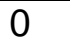 & & 24 & & 22 & & & & & & 100 & $100 \%$ \\
\hline 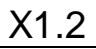 & 0 & $0 \%$ & & $8 \%$ & 30 & $30 \%$ & 58 & 58 & & $4 \%$ & 100 & 100 \\
\hline
\end{tabular}

Sumber : Hasil Penelitian, 2019 (Data Diolah)

Dari Tabel diatas dapat diketahui pernyataan variabel Relative Advantage (keuntungan relative) yaitu :

a. Untuk item pernyataan X1.1 menunjukkan frekuensi tertinggi sebesar 52\% (setuju) dan frekuensi yang paling rendah sebesar $0 \%$ (sangat tidak setuju).

b. Untuk item pernyataan $\mathrm{X} 1.2$ menunjukkan frekuensi tertinggi sebesar $58 \%$ (setuju) dan frekuensi

terendah sebesar 0\% ( sangat tidak setuju).

Berdasarkan hasil dari jawaban responden atas variabel Relative Advantage maka dapat disimpulkan bahwa sebagian besar responden mengatakan setuju bahwa Relative Advantage mempengaruhi pengadopsian bibit kelapa sawit bersertifikat.

2. Compatibility (Kesesuaian) 
Dalam hal ini dikemukakan angket mengenai Compatibility (Kesesuaian) yang merupakan variabel bebas dari penelitian, sebagaimana terlihat pada Tabel berikut, hasil persentase jawaban responden berdasarkan Compatibility.

Tabel 3: Responden terhadap Compatibility

\begin{tabular}{|c|c|c|c|c|c|c|c|c|c|c|c|c|}
\hline \multirow{2}{*}{ Butir } & \multicolumn{2}{|l|}{ STS } & \multicolumn{2}{|l|}{ TS } & \multicolumn{2}{|l|}{$\mathrm{N}$} & \multicolumn{2}{|l|}{$S$} & \multicolumn{2}{|l|}{ SS } & \multirow{2}{*}{$\begin{array}{l}\text { Total } \\
\text { F }\end{array}$} & \multirow{2}{*}{$\begin{array}{l}\text { Total } \\
\%\end{array}$} \\
\hline & $\mathrm{F}$ & $\%$ & $\mathrm{~F}$ & $\%$ & $\mathrm{~F}$ & $\%$ & $\mathrm{~F}$ & $\%$ & $\mathrm{~F}$ & $\%$ & & \\
\hline$X 2.1$ & 0 & $0 \%$ & 22 & $22 \%$ & 35 & $35 \%$ & 40 & $40 \%$ & 3 & $3 \%$ & 100 & $\%$ \\
\hline X2.2 & 0 & $0 \%$ & 4 & $4 \%$ & 40 & $40 \%$ & 53 & $53 \%$ & 3 & $\%$ & 100 & $\%$ \\
\hline
\end{tabular}

Sumber : Hasil Penelitian, 2019 (Data Diolah)

DariTabel diatas dapat diketahui pernyataan variabel Compatibility (Kompatibilitas) yaitu :

a. Untuk item pernyataan X2.1 menunjukkan frekuensi tertinggi sebesar $40 \%$ (setuju) dan frekuensi yang paling rendah sebesar $0 \%$ (sangat tidak setuju).

b. Untuk item pernyataan X2.2 menunjukkan frekuensi tertinggi sebesar $53 \%$ (setuju) dan frekuensi terendah sebesar $0 \%$ ( sangat tidak setuju).

Tabel 4 : Responden terhadap Complexity

\begin{tabular}{|c|c|c|c|c|c|c|c|c|c|c|c|c|}
\hline \multirow{2}{*}{ Butir } & \multicolumn{2}{|c|}{ STS } & \multicolumn{2}{|c|}{ TS } & \multicolumn{2}{|l|}{$\mathrm{N}$} & \multicolumn{2}{|l|}{$S$} & \multicolumn{2}{|c|}{ SS } & \multirow{2}{*}{$\begin{array}{l}\text { Total } \\
\text { F }\end{array}$} & \multirow{2}{*}{$\begin{array}{l}\text { Total } \\
\%\end{array}$} \\
\hline & $\mathrm{F}$ & $\%$ & $\mathrm{~F}$ & $\%$ & $\mathrm{~F}$ & $\%$ & $F$ & $\%$ & $\mathrm{~F}$ & $\%$ & & \\
\hline X3.1 & 0 & $0 \%$ & 11 & $11 \%$ & 44 & $44 \%$ & 40 & $40 \%$ & 5 & $5 \%$ & 100 & $100 \%$ \\
\hline X3.2 & 0 & $0 \%$ & 6 & $6 \%$ & 19 & $19 \%$ & 73 & $73 \%$ & 2 & $2 \%$ & 100 & $100 \%$ \\
\hline
\end{tabular}

Sumber : Hasil Penelitian, 2019 (Data Diolah)

DariTabel diatas dapat diketahui pernyataan variabel Complexity (Kompleksitas) yaitu :

a. Untuk item pernyataan X3.1 menunjukkan frekuensi tertinggi sebesar $44 \%$ (netral) dan frekuensi yang paling rendah sebesar $0 \%$ (sangat tidak setuju).

b. Untuk item pernyataan X3.2 menunjukkan frekuensi tertinggi sebesar $73 \%$ (setuju) dan frekuensi terendah sebesar $0 \%$ ( sangat tidak setuju).
Berdasarkan hasil dari jawaban responden atas variabel Compatibility maka dapat disimpulkan bahwa sebagian besar responden mengatakan setuju bahwa Compatibility mempengaruhi pengadopsian bibit kelapa sawit bersertifikat.

3. Complexity (Kerumitan)

Dalam hal ini dikemukakan angket mengenai Complexity (Kerumitan) yang merupakan variabel bebas dari penelitian, sebagaimana terlihat pada Tabel berikut, hasil persentase jawaban responden berdasarkan Complexity. 
Agriprimatech

Vol. 3 No. 2, April 2020

e-ISSN :2621-6566

Tabel 5 : Responden terhadap Triability

\begin{tabular}{|c|c|c|c|c|c|c|c|c|c|c|c|c|}
\hline \multirow{2}{*}{ Butir } & \multicolumn{2}{|c|}{ STS } & \multicolumn{2}{|c|}{ TS } & \multicolumn{2}{|l|}{$\mathrm{N}$} & \multicolumn{2}{|l|}{$S$} & \multicolumn{2}{|c|}{ SS } & \multirow{2}{*}{$\begin{array}{l}\text { Total } \\
\mathrm{F}\end{array}$} & \multirow{2}{*}{$\begin{array}{l}\text { Total } \\
\%\end{array}$} \\
\hline & $\mathrm{F}$ & $\%$ & $F$ & $\%$ & $F$ & $\%$ & $F$ & $\%$ & $\mathrm{~F}$ & $\%$ & & \\
\hline$X$ & 0 & $0 \%$ & 5 & $5 \%$ & 42 & $42 \%$ & 51 & $51 \%$ & 2 & $2 \%$ & 100 & $100 \%$ \\
\hline$X 4.2$ & 0 & $0 \%$ & 17 & $17 \%$ & 38 & $38 \%$ & 40 & $40 \%$ & 5 & $5 \%$ & 100 & $100 \%$ \\
\hline
\end{tabular}

Sumber : Hasil Penelitian, 2019 (Data Diolah)

DariTabel diatas dapat diketahui pernyataan variabel Triability (Uji Coba) yaitu :

a. Untuk item pernyataan X4.1 menunjukkan frekuensi tertinggi sebesar $51 \%$ (setuju) dan frekuensi yang paling rendah sebesar $0 \%$ (sangat tidak setuju).

b. Untuk item pernyataan X4.2 menunjukkan frekuensi tertinggi sebesar $40 \%$ (setuju) dan frekuensi terendah sebesar $0 \%$ ( sangat tidak setuju).

Berdasarkan hasil dari jawaban responden atas variabel Triability maka dapat disimpulkan bahwa sebagian besar responden mengatakan setuju bahwa Triability mempengaruhi pengadopsian bibit kelapa sawit bersertifikat.

5. Observability (Dapat Diamati)

Dalam hal ini dikemukakan angket mengenai Observability (Dapat Diamati) yang merupakan variabel bebas dari penelitian, sebagaimana terlihat pada Tabel berikut, hasil persentase jawaban responden berdasarkan Observability.

Tabel 6 : Responden terhadap Observability

\begin{tabular}{lllllllllllll}
\hline \multirow{2}{*}{ Butir } & STS & & TS & & N & & S & & SS & Total & Total \\
& $\mathrm{F}$ & $\%$ & $\mathrm{~F}$ & $\%$ & $\mathrm{~F}$ & $\%$ & $\mathrm{~F}$ & $\%$ & $\mathrm{~F}$ & $\%$ & $\mathrm{~F}$ & $\%$ \\
\hline X5.1 & 0 & $0 \%$ & 15 & $15 \%$ & 16 & $16 \%$ & 65 & $65 \%$ & 4 & $4 \%$ & 100 & $100 \%$ \\
$\mathrm{X} 5.2$ & 0 & $0 \%$ & 19 & $19 \%$ & 34 & $34 \%$ & 43 & $43 \%$ & 4 & $4 \%$ & 100 & $100 \%$ \\
\hline
\end{tabular}

Sumber : Hasil Penelitian, 2019 (Data Diolah)

DariTabel diatas dapat diketahui pernyataan variabel Observability (Dapat Diamati) yaitu :

a. Untuk item pernyataan X5.1 menunjukkan frekuensi tertinggi sebesar $65 \%$ (setuju) dan frekuensi yang paling rendah sebesar $0 \%$ (sangat tidak setuju).

b. Untuk item pernyataan $\times 5.2$ menunjukkan frekuensi tertinggi sebesar $43 \%$ (setuju) dan frekuensi terendah sebesar $0 \%$ ( sangat tidak setuju).

Berdasarkan hasil dari jawaban responden atas variabel Observability maka dapat disimpulkan bahwa sebagian besar responden mengatakan setuju bahwa Observability mempengaruhi Tabel 7 : Hasil Uji Validitas

pengadopsian bibit kelapa sawit bersertifikat.

\section{Metode Analisis Data}

Metode analisis data yang digunakan pada penelitian ini adalah analisis Regresi Berganda dengaan Pengolahan data SPSS versi 24. Adapun tahaptahapannya adalah sebagai berikut :

\section{Uji Validitas}

Dasar dalam pengambilan keputusan untuk uji validitas adalah dengan membandingkan nilai $r$-hitung dengan $r$ tabel. Variabel dikatakan valid jika nilai $r$ hitung > r-tabel dan nilai signifikansi < 0,10 . Hasil uji validitas dapat dilihat pada Tabel berikut :

\begin{tabular}{lllll}
\hline & & & & \\
Jenis variabel & r-hitung & r-tabel & signifikansi & kesimpulan \\
\hline $\mathrm{X} 1.1$ & 0,812 & 0,1654 & 0,000 & Valid \\
\hline
\end{tabular}




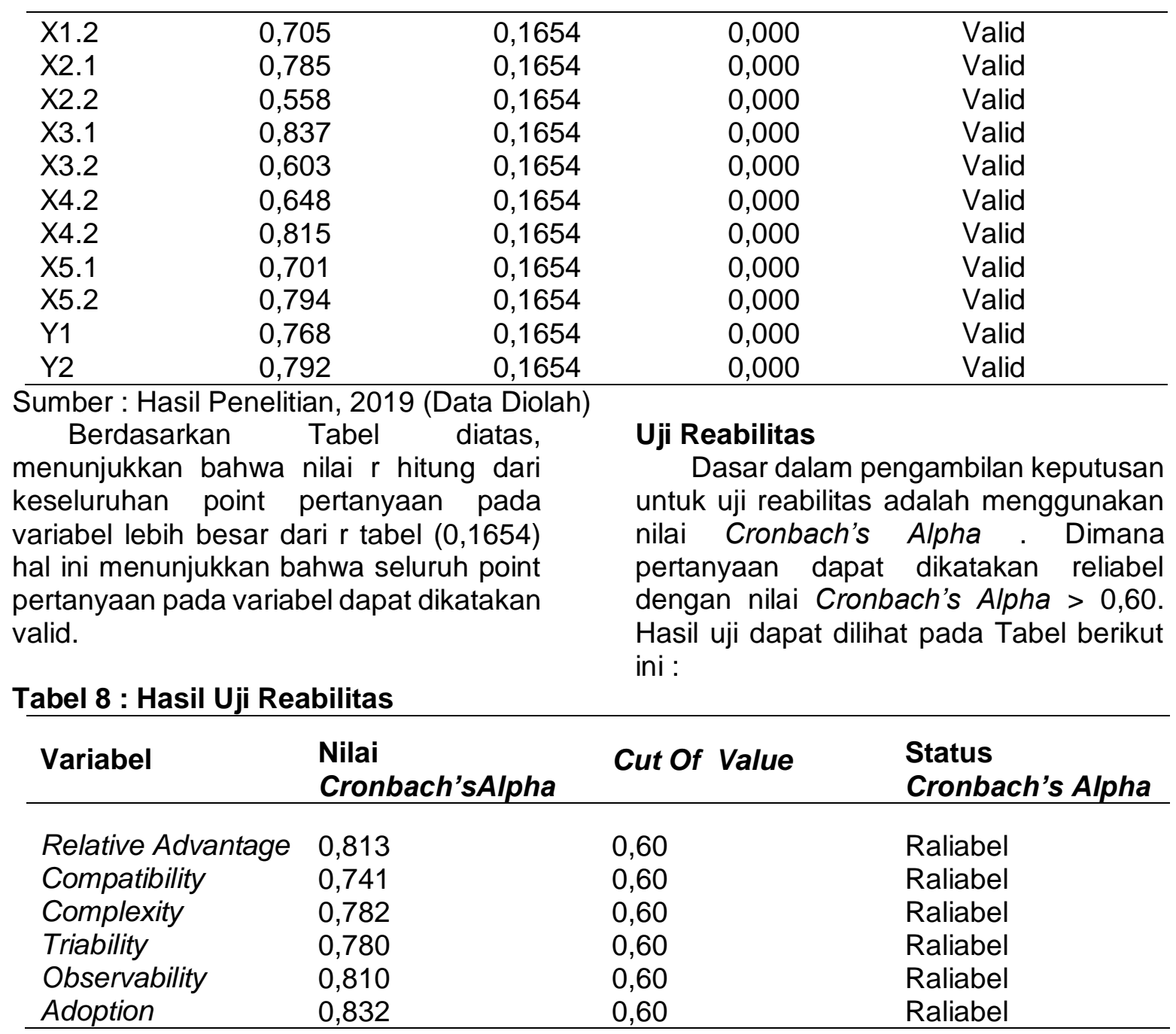

Sumber : Hasil Penelitian, 2019 (Data Diolah)

Berdasarkan Tabel diatas data hasil

uji reliabilitas dari masing-masing variabel diata angka 0,60 . Sehingga dapat disimpulkan bahwa kuesioner ini reliabel sebagai instrumen penelitian.

Uji Asumsi Klasik

Uji Asumsi Klasik dilakukan untuk mengetahui apakah data mengalami penyimpangan atau tidak. Uji asumsi klasik terdiri dari :

\section{Uji Normalitas}

$\begin{array}{ccc}\text { Uji normalitas } & \text { bertujuan } & \text { untuk } \\ \text { menguji apakah } & \text { data } & \text { yang } \\ \text { digunakandalam } & \text { model } & \text { regresi }\end{array}$ berdistribusi normal atau tidak. Setelah melakukan uji OneSample - Kolmogorov Smirnov, diperoleh signifikan sebesar $0,200>0,10$. Darihasil tersebut dapat disimpulkan bahwa data berdistribusi normal. Hasil ujinormalitas dapat dilihat pada Tabel 9, berikut : 
Tabel 9 : Hasil Uji Normalitas

One-Sample Kolmogorov-Smirnov Test

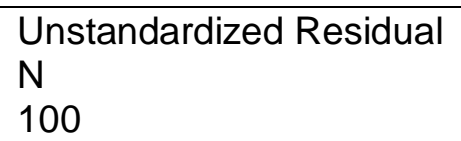

Normal Parameters ${ }^{a, b}$

Mean

.0000000

Std. Deviation

Most Extreme Differences

.97723201

$\begin{array}{ll}\text { Absolute } & .051 \\ \text { Positive } & .046 \\ \text { Negative } & -.051 \\ & .051 \\ & .200^{\mathrm{c}, \mathrm{d}}\end{array}$

Test Statistic

Asymp. Sig. (2-tailed)

\section{Sumber : Hasil Penelitian, 2019 (Data Diolah) \\ Pengaruh Variabel Relative Advantage, Compatibility, Complexity, Triability, dan Observability secara simultan terhadap Adoption.}

Berdasarkan hasil uji F diperoleh nilai signifikan adalah $0,000<$ dari 0,1 . Hal ini membuktikan bahwa relative advantage, compatibility, complexity, triability, dan observability berpengaruh secara bersama-sama (simultan) terhadap keputusan adoption. Berdasarkan analisis regresi berganda pada lampiran diperoleh nilai koefesien determinasi $\mathrm{R}$ Square $=$ 0,424 . Ini ditunjukkan bahwa $42,4 \%$ variasi variabel keputusan adopsi dipengaruhi oleh relative advantage, compatibility, complexity, triability, dan observability. Sisanya sebesar $57,6 \%$ dipengaruhi oleh variabel lain.Sehingga dapat diduga ada variabel lainnya selain relative advantage, compatibility, complexity, triability, dan observability yang mempengaruhi keputusan pengadopsian tapi belum dimasukkan dalam model. Adapun variabel lain yang mungkin terkait dengan pengadopsian adalah norma subjektif. Norma subjektif disini ialah peran dari KUD P3RSU (Proyek Pengembangan Perkebunan Rakyat Sumatra Utara). Responden yang diteliti merupakan anggota dari KUD P3RSU sehingga melalui KUD ini para petani ini mendapatkan masukan ataupun saran dari pengurus-pengurus KUD. Saran-saran ini diperoleh dari adanya penyuluhan-penyuluhan yang dilakukan pihak-pihak dinas terkait mengenai keunggulan-keunggulan dari bibit bersertifikat, inilah yang mendorongpetani sehingga berniat untuk menggunakan bibit kelapa sawit bersertifikat. 
Agriprimatech

Vol. 3 No. 2, April 2020

\section{Pengaruh Relative Advantage terhadap Adoption}

Berdasarkan hasil uji t pada tabel didapatkan koefisien pengaruh variabel dengan nilai signifikan $0,7 \%<$ pada $\alpha$ $10 \%$. Hal tersebut membuktikan bahwa relative advantage berpengaruh secara parsial terhadap keputusan adoption. Berdasarkan deskripsi variabel Relative Advantage yang merupakan variabel bebas dari penelitian, memiliki 2 pernyataan yaitu, menggunakan bibit kelapa sawit bersertifikat meningkat produktivitas kelapa sawit petani (X1.1) dan menggunakan bibit kelapa sawit bersertifikat dapat meningkatkan kualitas tanda buah kelapa sawit petani (X1.2). Pada pernyataan tersebut X1.2 memiliki frekuensi tertinggi sebesar $58 \%$ (setuju) hal ini menunjukkan bahwa petani merasakan keuntungan yang relatif karena dengan menggunakan bibit kelapa sawit bersertifikat dapat meningkatkan kualitas tanda buah kelapa sawit.

Sehingga hasil penelitian ini sependapat dengan Situmorang (2015) yang menjelaskan bahwa dalam hasil penelitiannya relative advantage merupakan tingkat ukur dimana suatu program dapat memberikan suatu keuntungan kepada pelaksananya. Sejalan dengan Roger (2001) yang mengemukakan bahwa relative advantage adalah tingkatan dimana suatu ide baru dianggap sesuatu yang lebih baik. Tingkat keuntungan relative advantage sering kali dinyatakan dalam bentuk keuntungan ekonomis dimana penelitian ini petani puas dengan menggunakan bibit kelapa sawit bersertifikat. Jadi relative advantage mempengaruhi petani untuk mengadopsi bibit kelapa sawit bersertifikat.

\section{Pengaruh Compatibility terhadap Adoption}

Berdasarkan uji $t$ pada tabel didapatkan koefisien tidak adanya pengaruh variabel dengan nilai signifikan

$$
\text { e-ISSN : 2621-6566 }
$$

$18 \%>$ pada a $10 \%$. Hasil penelitian dari compatibility tidak berpengaruh secara parsial terhadap keputusan adoption. Hasil deskripsi variabel Compatibility yang merupakan variabel bebas dari penelitian, memiliki 2 pernyataan yaitu bibit kelapa sawit bersertifikat cocok dengan gaya kerja petani (X2.1) dan menggunakan bibit kelapa sawit bersertifikat sesuai dengan informasi yang didapat oleh petani (X2.2).

Pada pernyataan tersebut X2.2 memiliki frekuensi tertinggi sebesar $53 \%$ (setuju) hal ini menunjukkan bahwa kesesuaian petani menggunakan bibit kelapa sawit bersertifikat sesuai dengan informasi yang didapat sehingga petani tidak lagi membutuhkan informasi untuk mengadopsi bibit bersertifikat. Situmorang (2015) menjelaskan bahwa tingkat keselarasan merupakan tingkat ukur dimana suatu program dianggap sesuai dengan latar belakang kehidupan masyarakat, baik dari tingkat pendidikan maupun motivasi.

\section{Pengaruh Complexity terhadap Adoption}

Berdasarkan uji $t$ pada tabel didapatkan koefisien pengaruh variabel dengan nilai signifikan $0,7 \%<$ dari $\alpha 10 \%$. Hasil tersebut membuktikan bahwa complexity berpengaruh secara parsial terhadap keputusan adoption. Berdasarkan deskripsi variabel Complexity yang merupakan variabel bebas dari penelitian, memiliki 2 pernyataan yaitu bibit kelapa sawit bersertifikat sangat mudah untuk digunakan mapun perawatannya (X3.1) dan bibit kelapa sawit bersertifikat mudah untuk didapatkan (X3.2).

Pada pernyataan tersebut X3.2 memiliki frekuensi tertinggi sebesar $73 \%$ (setuju) hal ini menunjukkan bahwa tidak adanya kerumitan untuk mendapatkan bibit kelapa sawit bersertifikat. Kemudahan ini menjadi salah satu faktor petani mau menggunakan bibit kelapa 
Agriprimatech

Vol. 3 No. 2, April 2020

sawit bersertifikat. Hal ini didukung oleh Roger (2001) yaitu jika suatu inovasi semakin mudah dipahami dan dimengerti oleh pengadopsi, maka semakin cepat suatu inovasi dapat diadopsi.

\section{Pengaruh Triability terhadap Adoption}

Berdasarkan uji $t$ pada tabel didapatkan koefisien pengaruh variabel dengan nilai signifikan $0 \%<$ dari $\alpha 10 \%$. Hasil tersebut membuktikan triability berpengaruh secara parsial terhadap keputusan adoption. Berdasarkan deskripsi variabel Triability yang merupakan variabel bebas dari penelitian, memiliki 2 pernyataan yaitu petani suka memilih bibit kelapa sawit bersertifikat yang telah dicoba sebelumnya (X4.1) dan bibit kelapa sawit bersertifikat yang sudah diuji coba menjadi penting dalam keputusan petani untuk menggunakannya (X4.2).

Pada pernyataan tersebut $\mathrm{X} 4.1$ memiliki frekuensi tertinggi sebesar $51 \%$ (setuju) hal ini menunjukkan bahwa petani lebih suka menggunakan bibit kelapa sawit bersertifikat yang telah dilakukan uji coba sehingga bibit kelapa sawit bersertifikat yang telah diuji coba menjadi penting dalam pengambilan keputusan untuk petani. Roger (2001) menjelaskan bahwa suatu inovasi agar cepat diadopsi, sebaiknya harus mampu menunjukkan keunggulannya.

\section{Pengaruh Observability terhadap Adoption}

Berdasarkan uji $t$ pada tabel didapatkan koefisien tidak adanya pengaruh variabel dengan nilai signifikan $12,6 \%>$ dari a 10 . Hasil penelitian dari observability tidak berpengaruh secara parsial terhadap keputusan adoption. Berdasarkan deskripsi variabel Observability yang merupakan variabel bebas dari penelitian, memiliki 2 pernyataan yaitu para petani lain tertarik pada bibit kelapa sawit bersertifikat ketika petani tersebut menggunakannya (X5.1)

$$
\text { e-ISSN : 2621-6566 }
$$

dan orang-orang mengatakan bahwa petani tersebut tau lebih banyak tentang bibit kelapa sawit bersertifikat karena sudah melakukan uji coba.

Pada pernyataan tersebut X5.1 memiliki frekuensi tertinggi sebesar $65 \%$ (setuju) hal ini menunjukkan bahwa petani yang telah menggunakan bibit kelapa sawit bersertifikat menjadi objek pengamatan untuk petani lain sehingga petani lain tertarik menggunakan bibit kelapa sawit bersertifikat. Sehingga hasil penelitian ini sejalan dengan Roger (2001) yaitu hasil suatu inovasi dapat dilihat oleh orang lain. Hasil inovasiinovasi tertentu mudah dilihat dan dikomunikasikan kepada orang lain. Jika inovasi itu dapat terlihat, maka calon adopsi lainnya tidak perlu lagi menjalani tahap percobaan, melainkan dapat terus ketahap adopsi.

\section{KESIMPULAN}

Berdasarkan hasil penelitian diatas dapat ditarik kesimpulan, yaitu:

1. Faktor-faktor yang mempengaruhi petani Adopsi bibit kelapa sawit ada 5 yaitu Relative Advantage, Compatibility, Complexity, Triability, dan Observability sebesar 42,4\% yang diperoleh dari nilai koefisien determinasi R-Square $=0,424$. Selebihnya $57,6 \%$ dipengaruhi oleh variabel lain yang tidak dimasukkan kedalam penelitian.

2. Pengaruh variabel independen terhadap dependen, yaitu :

a. Relative Advantage berpengaruh secara parsial terhadap Adoption

b. Compatibility tidak berpengaruh secara parsial terhadap Adoption

c. Complexity berpengaruh secara parsial terhadap Adoption

d. Triability berpengaruh secara parsial terhadap Adoption

e. Observability tidak berpengaruh secara parsial terhadap Adoption 
Agriprimatech

Vol. 3 No. 2, April 2020

\section{DAFTAR PUSTAKA}

Azwar, S. 2003. Sikap Manusia: Teori dan Pengukurannya. Yogyakarta. Liberty.

[Ditjen] Direktorat Jenderal Perkebunan. 2013. Statistik Perkebunan Indonesia 2014-2016: Kelapa Sawit. Jakarta: Direktorat Jenderal Perkebunan.

Goenadi. 2008. Potensi Produktivitas Bibit Kelapa Sawit Baru Jenis Unggul. Bogor: Lembaga Riset Perkebunan Indonesia.

Gonzales, H.1977. Difusi dan Umpan Balik. Amri Jahi, Penerjemah;Amir Jahi, Editor Komunikasi Massa dan Pembangunan Pedesaan dan Negara-negara Dunia Ketiga. Jakarta:PT.Gramedia. Terjemahan dari:Diffusion and Feedback

Henson. 1990. Kesenjangan dan potensi produktivitas sawit di Indonesia. Dalam: Manfaat Minyak Sawit Bagi Perekonomian Indonesia. Laporan World Growth, Februari 2011.

Jannah, N.A. Fatah \& Marhanudin,2012.Pengaruh macam dan dosis pupuk NPK majemuk terhadap pertumbuhan bibit kelapa sawit (Elaeis guineensis Jack). Samarinda.

Kiswanto, et al.,(2008). Teknologi Budidaya Sawit. Bogor. Badan Penelitian dan Pengembangan Pertanian.

Lestari, S. B. dkk. 2001. Manajemen dan Komunikasi Penyuluhan. Yogyakarta: Penyuluhan dan Komunikasi, Universitas Gajah Mada.

Liang, S.-W., \& Lu, H.-P. 2013. "Adoption of E-Government Services: An Empirical Study of The Online Tax Filing System in Taiwan". Online Information Review Vol.37, No.3, 424-442.
e-ISSN :2621-6566

Mardikanto. 1993. Penyuluhan Pembangunan Pertanian Dalam Teori dan Praktek. Hapsari. Jakarta. [PPKS] Pusat Perkebunan Kelapa Sawit. 2008. Benih Sawit Bermutu vs Benih Sawit Palsu. Medan: Pusat Perkebunan Kelapa Sawit. 2003. Budidaya Kelapa Sawit. Dalam L.Buana, D. Siahaan, dan S.Adi Putra (Eds). Kultur Teknis Kelapa Sawit. Pusat Penelitian Kelapa Sawit. Medan. 2006. Potensi dan Peluang Investasi Industri Kelapa Sawit di Indonesia. Dalam Latif, $S$ (Ed). Potensi dan Peluang Investasi Industri Kelapa Sawit di Indonesia. Pusat Penelitian Kelapa Sawit. Medan.

[Pusdatin Info Pertanian] Pusat Data danInformasi

Pertanian.2010.Outlook

KomoditasPertanian

Perkebunan.Jakarta :Kementrian Pertanian.

Purba, R., Witjaksono, dan Bambang. 2006. Bibit Kelapa Sawit Tidak Bersertifikat Penghambat Peningkatan Produktivitas. Bogor: Lembaga Riset Perkebunan Indonesia.

Rao, Purba. 1996."Measuring Consumer Perceptions Throigh Factor Analysis". The Asian Manager ( February March).

Rogers, E.M. dan Shoemaker, F.F. 1983. Diffusion of Innovation. Dalam Ningtyas, R. A., Astiti, N. W. S., dan Handayani, M. 2016. Tingkat Adopsi Sistem Tanam Jajar Legowo 2: 1 di Kelompok Tani Mina Sri Jaya Desa Sepanjang Kecamatan Glenmore Kabupaten Banyuwangi Jawa Timur. Journal of Agribusiness and Agritourism.

Rogers, E. M. 2001.Diffusion of Innovation. London: Macmillan Publishing Co. Inc. 
Silala, V. 2003. Upaya-Upaya Memperkecil Peredaran Bibit Kelapa Sawit Palsu. Sebelat: PT Agricinal.

Situmorang, B., Edwina S, Maharani E. 2015. Adopsi Inovasi Petani Kelapa Sawit Terhadap Sistem Integrasi Sapi - Kelapa Sawit (SISKA) di Kabupaten Pelalawan. .Faperta2(1).http://jom.unri.ac.id/in dex.php/JOMFAPERTA/article/dow nload/5470/5349. Diakses pada 17 September 2017.

Sobur A. 2003. Psikologi Umum Dalam Lintas Sejarah. Bandung :CV. Pustaka Setia.

Soekartawi. 2005. Prinsip Dasar Komunikasi Pertanian. Universitas Indonesia Press. Jakarta.

Sugiyono, 2013. Metode Penelitian Pendidikan Pendekatan Kuantitatif dan Kualitatif dan R\&D. Bandung:Alfabeta.

Suparta, N. 2001. Perilaku Agribisnis dan Kebutuhan Penyuluhan Peternak Ayam Ras Pedaging.[Disertai]. Bogor. Institut Pertanian Bogor, Program Pascasarjana.

Humaeda, Ume. 2007. Peranan Kontaktani dalam Difusi Inovasi di Kabupaten Pandeglang Banten. Bogor. Institute Pertanian Bogor, Program Pascasarjana.

Van den Ban dan H.S Hawkins. 2003. Penyuluhan Pertanian (terjemahan Agricultural Extension). Yogyakarta: Penerbit Kanisius.

Wigena, I.G.P., Dkk. 2009. Karakteristik tanah dan ilklim serta kesesuaian untuk kebun kelapa sawit plasma di Sei Pagar, Kabupaten Kampar, Provinsi Riau. Jurnal tanah dan iklim (30): hal $1-2$. 